\title{
Metformin Inhibits Proliferation and Tumor Growth of QGP-1 Pancreatic Neuroendocrine Tumor Cells by Inducing Cell Cycle Arrest and Apoptosis
}

\author{
HIROKI YAMANA ${ }^{1}$, KIYOHITO KATO ${ }^{1}$, HIDEKI KOBARA ${ }^{1}$, SHINTARO FUJIHARA ${ }^{1}$, KOJI FUJITA ${ }^{1}$, \\ DAISUKE NAMIMA ${ }^{1}$, NAOKI FUJITA ${ }^{1}$, KIYOYUKI KOBAYASHI $^{1}$, HIDEKI KAMADA $^{1}$, \\ ASAHIRO MORISHITA ${ }^{1}$, KUNIHIKO TSUTSUI $^{1}$, HISAKAZU IWAMA ${ }^{2}$ and TSUTOMU MASAKI $^{1}$ \\ ${ }^{1}$ Department of Gastroenterology and Neurology, Kagawa University, Kagawa, Japan; \\ ${ }^{2}$ Life Science Research Center, Kagawa University, Kagawa, Japan
}

\begin{abstract}
Background/Aim: Pancreatic neuroendocrine tumors (pNETs) are rare pancreatic neoplasms, and therapeutic options for pNETs are limited. Metformin is an anti-hypoglycemic drug that appears to have anticancer effects. However, little is known about the effect of metformin on pNETs. In this study, we investigated the anti-proliferative effect of metformin on a human pNET cell line. Materials and Methods: The anti-proliferative properties of metformin were evaluated in QGP-1 and NCI-H727 cells using a cell counting kit-8 assay. Xenograft mouse models were used to assess the tumor effect in vivo. Results: Metformin inhibited the proliferation and anti-tumor growth of QGP-1 cells, accompanied by their arrest during the cell cycle at the $G_{0 /} G_{1}$ phase. Immunohistochemical analysis of tumor tissues revealed down-regulation of cyclin D1 and proliferating cell nuclear antigen in the metformin-treated group. Additionally, metformin induced apoptosis, and the expression of survivin and claspin were decreased in metformin-treated QGP-1 cells according to the apoptosis array. Furthermore, the angiogenic related protein TIMP-1 was down-regulated, and its miRNA expression was altered by metformin in QGP-I cells. Conclusion: Taken together, our study demonstrated the therapeutic potential of metformin and provides molecular mechanistic insights into its anti-tumoral effect on pNETs. This study is the first one describing anti-tumoral effects in pNETs.
\end{abstract}

Correspondence to: Tsutomu Masaki, Department of Gastroenterology and Neurology, Kagawa University, Faculty of Medicine, Graduate School of Medicine, 1750-1 Ikenobe, Miki-cho, Kita-gun, Kagawa 761-0793, Japan. Tel: +81 878912156, Fax: +81 878912158, e-mail: tmasaki@med.kagawa-u.ac.jp

Key Words: Pancreatic neuroendocrine tumor, metformin, cell cycle, apoptosis, microRNA.
Pancreatic neuroendocrine tumors (pNETs) are overall rare, and represent less than $3 \%$ of primary pancreatic tumors (1, 2 ). The incidence of pNETs is increasing and approximately $50 \%$ of patients have advanced disease at diagnosis (3). Most pNETs are sporadic, but they can be associated with hereditary diseases, including multiple endocrine neoplasia type 1, Von Hippel Lindau syndrome, neurofibromatosis type 1 , and tuberous sclerosis (4). Therapeutic options for pNETs include surgical resection, systemic chemotherapy, such as somatostatin analogues, the mechanistic target of rapamycin (mTOR) inhibitor everolimus, the multikinase inhibitor sunitinib, and peptide receptor radiotherapy (5). Surgery is the only curative modality for sporadic pNETs and the 5-year survival rate is $32 \%$ for patients with advanced pNETs, thus, the prognosis is poor (6). Accordingly, there is a need to develop more effective treatments for pNETs.

Metformin is an anti-hypoglycemic drug that is widely prescribed for the treatment of type 2 diabetes mellitus (7). It has been associated with reduced incidence of several types of cancer in patients with diabetes mellitus $(8,9)$. Metformin exerts its anti-proliferative effects partly by activating AMP-activated protein kinase that plays a key regulatory role in maintaining cellular energy homeostasis. Additionally, metformin induces cell cycle arrest and apoptosis, and down-regulates growth factor receptors to inhibit angiogenesis of various cancers $(10,11)$. According to recent studies, metformin in combination with a somatostatin analog and everolimus improve clinical outcomes of pNETs, including progression-free survival (12). However, the detailed mechanism of the antiproliferative effects of metformin in pNETs remains unclear.

Cyclin D1 and cyclin-dependent kinase (Cdk) complexes play a critical role in $\mathrm{G}_{1} / \mathrm{S}$ phase of cell cycle progression (13). In particular, cyclin $\mathrm{D} 1$, a key regulator of $\mathrm{G}_{1} / \mathrm{S}$ transition in the cell cycle, is dysregulated in a variety of human cancers including certain endocrine tumors. Overexpression of cyclin 
D1 is frequently observed in pNETs compared with normal pancreatic tissue (14). Hence, restoring cell cycle progression may be an effective treatment strategy for pNETs.

In this study, we evaluated the anti-tumor effect of metformin in QGP-1 human pNET cells. The results revealed that metformin inhibited the proliferation of QGP-1 cells and induced cell cycle arrest, apoptosis, angiogenesis, and microRNA expression. Furthermore, metformin reduced the tumor burden in a QGP-1 xenografted animal model.

\section{Materials and Methods}

Drugs, chemicals and reagents. Metformin was obtained from Astellas Pharma (Tokyo, Japan). RPMI-1640 was obtained from Gibco BRL Life Technologies (Grand Island, NY, USA). Trypan Blue was purchased from Sigma-Aldrich (St Louis, MO, USA). Fetal Bovine serum (FBS) was obtained from Wako Pure Chemical Industries (Osaka, Japan). Penicillin-streptomycin was obtained from Invitrogen (Tokyo, Japan). The cell counting kit-8 (CCK-8) was obtained from Dojindo Laboratories (Kumamoto, Japan). The Cell Cycle Phase Determination Kit was obtained from Cayman Chemical (MI, USA). The annexin V-FITC Early Apoptosis Detection Kit was obtained from Cell Signaling Technology (Boston, MA, USA). The protease inhibitor cocktail was obtained from iNtRON Biotechnology (Sungnam, Republic of Korea). The Proteome Profiler Human Apoptosis and Angiogenesis Antibody Array Kits were obtained from R\&D Systems (Minneapolis, MN, USA). Primary antibodies against Cdk4, Cdk6, retinoblastoma protein $(\mathrm{Rb})$ were obtained from Santa Cruz Biotechnology (San Diego, CA, USA). Cyclin D1 was obtained from Thermo Fisher Scientific (Waltham, MA, USA). The antibody against $\beta$-actin was obtained from Sigma-Aldrich (St. Louis, MO, USA). Phosphorylated $\mathrm{Rb}$ was obtained from BD Pharmingen (San Diego, CA, USA).

Goat anti-mouse IgG-horseradish peroxidase (HRP) secondary antibodies, and goat anti-rabbit IgG- HRP were obtained from GE Healthcare (Chalfont, UK).

Cell culture. The human pancreatic neuroendocrine tumor (NET) cell line QGP-1 was provided by the Japanese Cancer Research Resources Bank. The typical bronchial carcinoid cell line NCI-H727 was obtained from the ATCC (Manassas, VA, USA). QGP-1 and $\mathrm{NCI}-\mathrm{H} 727$ cells were maintained at $37^{\circ} \mathrm{C}$ with $5 \% \mathrm{CO}_{2}$ in RPMI1640 medium supplemented with $10 \%$ fetal bovine serum, $20 \mathrm{U} / \mathrm{ml}$ penicillin, and $100 \mu \mathrm{g} / \mathrm{ml}$ streptomycin.

Cell proliferation assay. The cell proliferation assay was performed as described previously (15). Briefly, cell proliferation assays were conducted using a cell counting kit-8 (CCK-8) according to the manufacturer's instructions. And, these assays were conducted in QGP-1 and NCI-H727 cell lines. Then, 5.0x $10^{3}$ cells of each experiment group were equally seeded on 96-well plates and were treated as indicated for $72 \mathrm{~h}$ before cell proliferation assay. The absorbance was measured at $450 \mathrm{~nm}$ in each well using an automated microplate reader.

Cell cycle and apoptosis analyses. Cell cycle and apoptosis analysis was performed as described in our previous study (15). Briefly, QGP-1 cells were collected and seeded into $100-\mathrm{mm}$ culture dishes at $1.0 \times 10^{6}$ per dish, then maintained for $24 \mathrm{~h}$. Next, cells were treated with $5 \mathrm{mM}$ metfromin for 24-72 h. Cell cycle and apoptosis were determined by flow cytometry using Cytomics FC 500 flow cytometer (Beckman Coulter, Indianapolis, IN, USA), according to the manufacture's protocol. The percentages of cells were analyzed using Kaluza software (Beckman Coulter, Indianapolis, IN, USA).

Western blotting. Gel electrophoresis and western blotting were performed in accordance with our previously described methods (15). Briefly, proteins were subjected to sodium dodecyl sulfate polyacrylamide gel electrophoresis and then transferred to nitrocellulose membranes.

After blocking in 5\% dry skim milk in $0.05 \%$ Tween-20/TBS buffer, the membranes were incubated with primary antibodies, followed by peroxidase-conjugated secondary antibodies in 5\% dry skim milk in $0.05 \%$ Tween-20/TBS buffer.

Analysis of apoptosis and angiogenesis related protein profiles using an antibody array. QGP-1 cells were collected and seeded into 100mm culture dishes at $1.0 \times 10^{6}$ per dish, then maintained for $24 \mathrm{~h}$. Subsequently, the cells were treated with $5 \mathrm{~m} \mathrm{M}$ metformin for $48 \mathrm{~h}$. The cells were lysed in PRO-PREP (iNtRON Biotechnology). The membrane provided was blocked in blocking solution reagent and treated overnight with cell lysates protein. The membrane was washed and subsequently incubated with detection antibody cocktail and streptavidin horseradish peroxidase-conjugated. Chemiluminescent reagents were added to the membrane and then exposed to X-ray film to detect the protein expression levels in treated cells compared to untreated cells.

MiRNA array. MiRNA array analysis was performed as described in our previous study (15).

Briefly, total RNA was isolated using a miRNeasy Mini Kit (Qiagen, Hilden, Germany) from QGP-1 cells according to the manufacturer's instructions. MiRNA expression analysis was performed using the a miRCURYHy3/Hy5 Power Labeling Kit and human miRNA Oligo chip (v. 21.0; Toray Industries, Tokyo, Japan). The arrays were scanned in a 3D-Gene Scanner 3000 (Toray Industries), and these fluorescence images were analyzed using the 3D-Gene extraction version 1.2 software (Toray Industries).

Xenografted tumor model. All animals were treated in accordance with the guidelines of the Kagawa University Committee on Experimental Animals. Kagawa University Animal Care Committee approved our animal protocols including animal ethics. Six-weekold BALB/c-nu/nu mice $(n=24)$ were obtained from Japan SLC (Shizuoka, Japan) and housed under barrier conditions. A standard sterilized laboratory diet and water were available ad libitum. The mice were subcutaneously inoculated with QGP-1 cells $\left(1.0 \times 10^{6}\right.$ /animal) in their flanks. After approximately 2 weeks, when tumors reached a maximal diameter of $>3 \mathrm{~mm}, 24$ mice were randomly assigned into three groups. Mice were administrated PBS only (control) $(\mathrm{n}=8), 1 \mathrm{mg} /$ day metformin $(\mathrm{n}=8)$, or $2 \mathrm{mg} /$ day metformin $(n=8)$ intraperitoneally (i.p.). The mice were monitored for body weight and tumor volume every 3 days. Tumor volumes were calculated using the formula: $V=$ length $\times$ width $2 / 2$, as reported previously (16). The animals were sacrificed on day 22 following the beginning of each treatment.

Immunohistochemistry. We prepared $5 \mu \mathrm{m}$-thick sections from formalin-fixed, paraffin-embedded tissue blocks. To retrieve antigens, the sections were boiled in $10 \mathrm{mmol} / \mathrm{l}$ citrate buffer $(\mathrm{pH}$ 
A

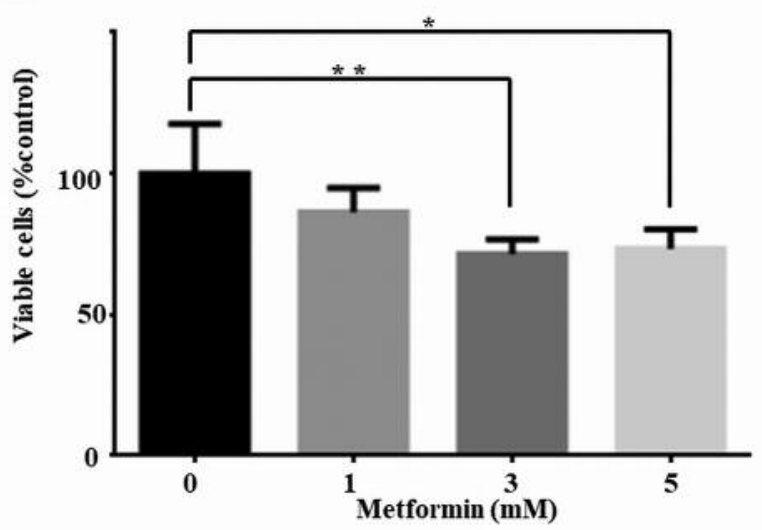

B

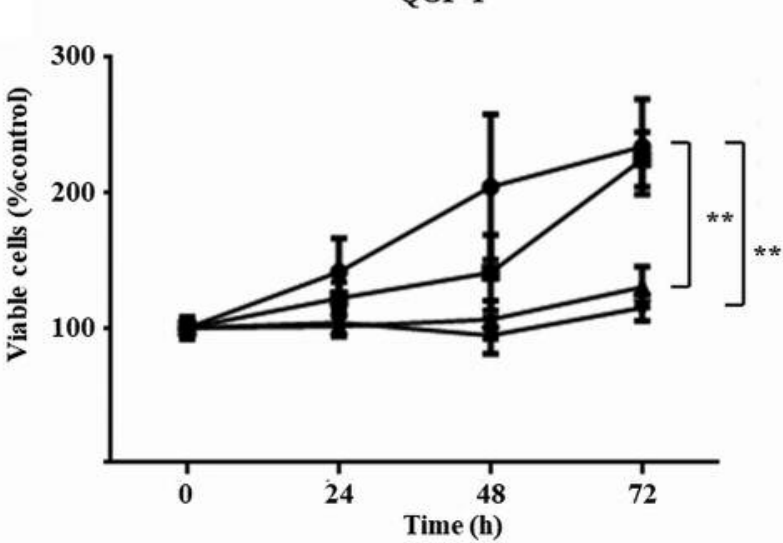

NCI-H727
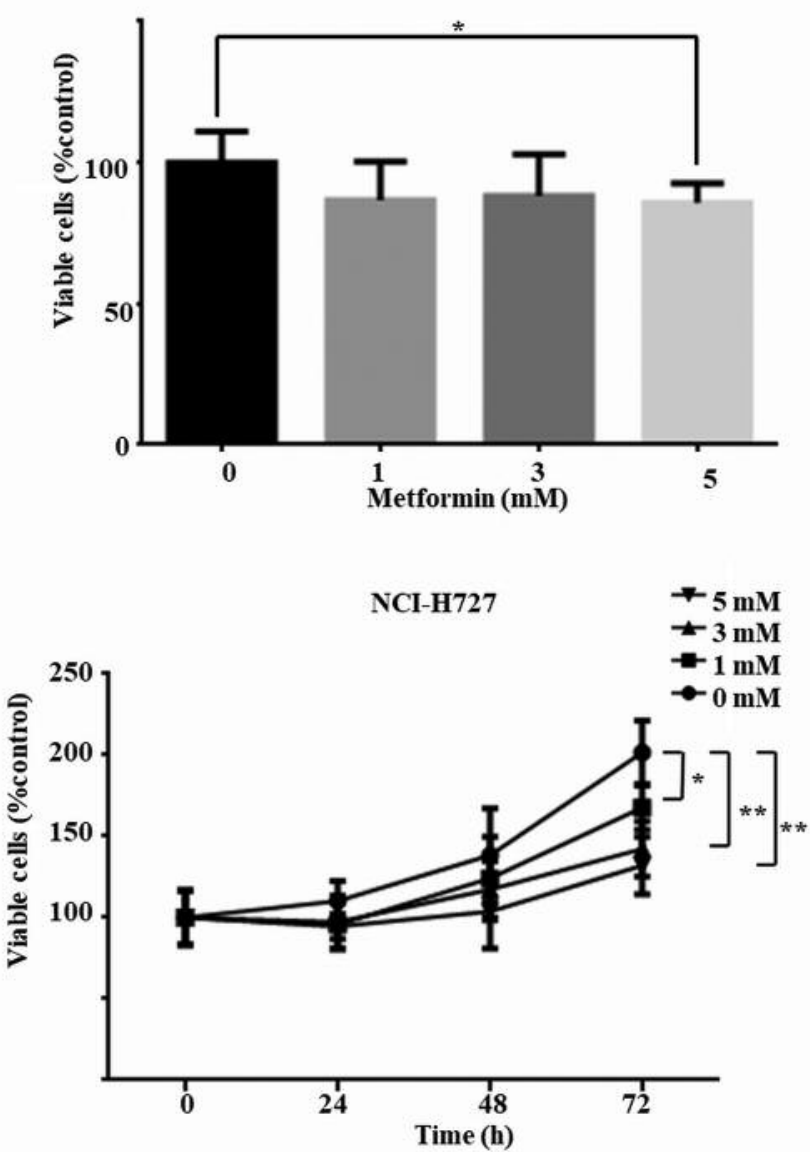

Figure 1. (A) After $24 \mathrm{~h}$, metformin (1,3, or $5 \mathrm{mmol} / \mathrm{l})$ was added to the culture medium. The results are expressed as the percentage of viable cells compared to the control $(0 \mathrm{mmol} / \mathrm{l})$. According to the Student's t-test, all treatments were significantly different from the control. $\left({ }^{*} p<0.05, * * p<0.01\right.$, and $* * * p<0.001$, vs control). (B) Metformin inhibits the proliferation of neuroendocrine tumor cells. QGP-1 and NCI-H727 cells were treated with 0, 1, 3, or $5 \mathrm{mM} \mathrm{metformin}$ for 0, 24, 48, and $72 \mathrm{~h}$. Cell viability was assessed by CCK-8 assays. Data points represent the mean cell number in three independent cultures, and error bars represent standard errors. For each cell line, the conditions at $72 \mathrm{~h}$ were significantly different compared with the control $(0 \mathrm{mmol} / \mathrm{l})(\mathrm{p}<0.01)$.

6.0) using a microwave oven (MR-M201 Microwave Processor; Hitachi, Tokyo, Japan) at $500 \mathrm{~W}$ for $5 \mathrm{~min}$. The sections were then dewaxed in xylene, rehydrated in graded alcohol solutions, and then mixed with a solution containing $0.5 \%$ hydrogen peroxidase to block endogenous peroxidase activity. After washing with phosphatebuffered saline, the sections were immunostained. Expression of PCNA and cyclin D1 were determined by incubation with a mouse $\mathrm{mAb}$ (1:200 dilution) and rabbit pAb (1:50 dilution), respectively, overnight. Then, the sections were incubated for $30 \mathrm{~min}$ with appropriate peroxidase-conjugated secondary antibodies (PK-6102, PK-6101, Vectastain Elite ABC kit, Vector Laboratories, CA, USA).

The standard avidin-biotin-peroxidase complex method (Funakosi Chemical Co., Tokyo, Japan) with diaminobenzidine (Sigma Chemical Co., Tokyo, Japan) as the substrate was employed for detection. Sections were then counterstained by Meyer's hematoxylin. Samples treated with phosphate buffer served as the negative control. Sections were examined microscopically for specific staining, and nuclei with a brown color regardless of staining intensity were regarded as positive. PCNA and cyclin D1 positivity was calculated for both at $\times 40$ magnification by dividing the number of positive cells by the total number of cells counted in five random fields and expressed as a percentage. Images were obtained with a digital image capture system (Olympus, Japan).

Statistical analysis. All statistical analyses were performed using GraphPad Prism 6 software (GraphPad Software, La Jolla, CA, USA). Data were analyzed using the unpaired Student's $t$-test and $p<0.05$ was considered to be statically significant.

\section{Results}

In vitro metformin treatment inhibits human NET cell growth by inducing cell cycle arrest at $G_{0} / G_{1}$ phase. Two human pancreatic neuroendocrine tumor (NET) cell lines, QGP-1 and NCI-H727, were treated with various concentrations of 


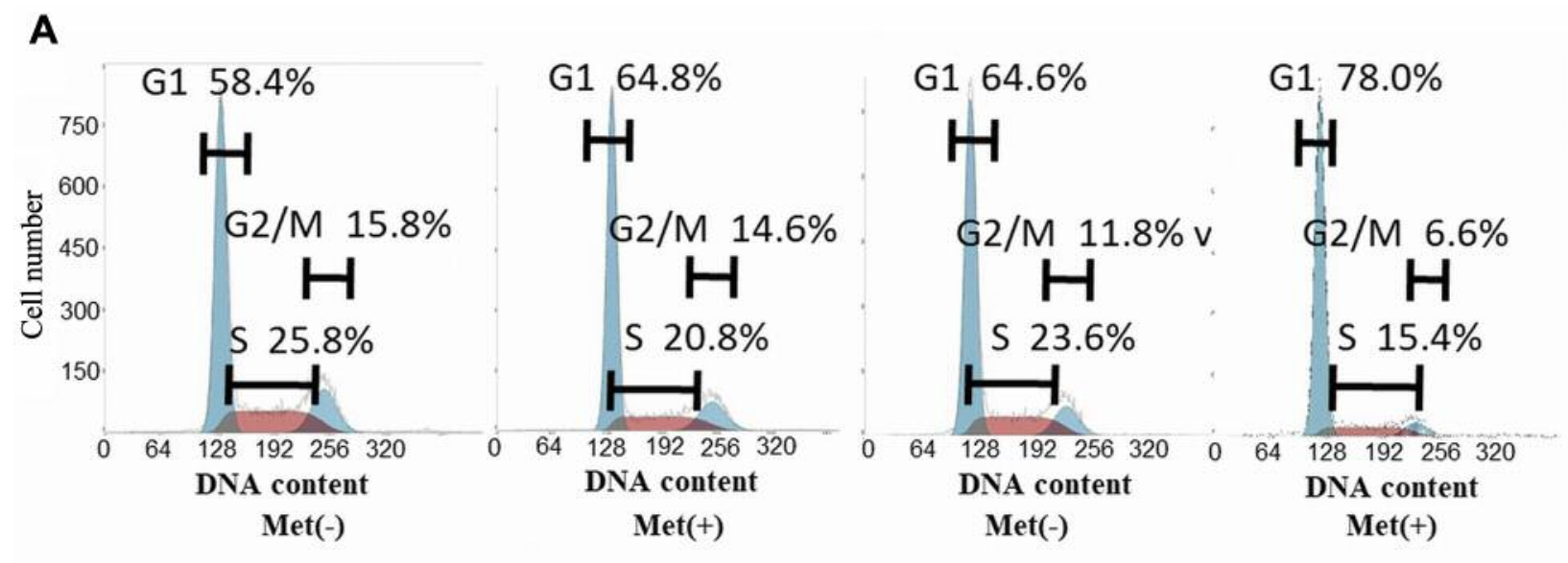

$24 \mathrm{~h}$

$48 \mathrm{~h}$
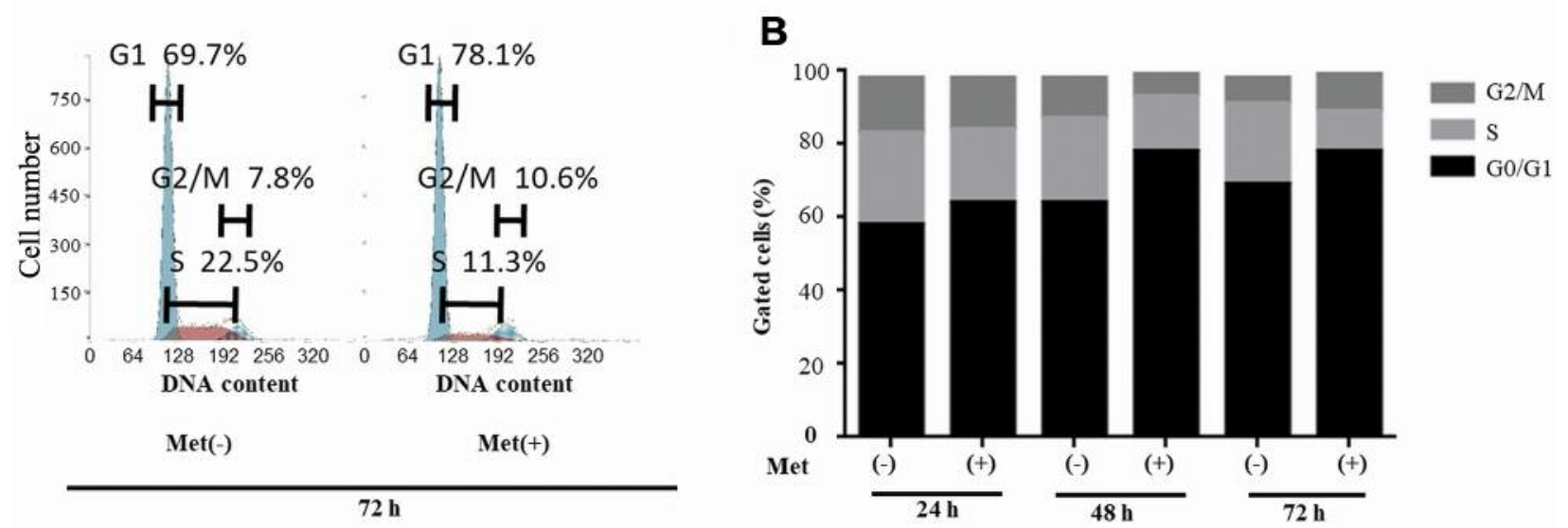

Figure 2. Metformin induces cell cycle arrest at $G_{0} / G_{1}$ in $Q G P-1$ cells. (A) Representative results showing the distribution of $Q G P-1$ cells in $G_{0} / G_{1}$, $S$, and $G_{2} / M$ phases following treatment with metformin $(5 \mathrm{mM})$ or without at 24 and $48 \mathrm{~h}$. (B) Histograms showing the percentage of QGP-1 cells in $G_{0} / G_{1}, S$, and $G_{2} / M$ phases.

metformin $(0,1,3$, or $5 \mathrm{mM})$ for consecutive days. Metformin reduced the proliferation of QGP-1 and NCI-H727 cells at 24 $\mathrm{h}$ of treatment (Figure 1A and B). These results demonstrated that metformin inhibited cell proliferation of NET cell lines in a dose-dependent manner.

We further investigated the effects of metformin on the cell cycle of QGP-1 cells by flow cytometric analysis (Figure 2A). When QGP-1 cells were incubated with $5 \mathrm{mM}$ metformin, the number of cells in proliferative $S$ and $G_{2} / M$ fraction was decreased and those in non-proliferative $G_{0} / G_{1}$ fraction increased (Figure 2B). Furthermore, the expression level of cyclin D1 was decreased in QGP-1 cells, while expression of Cdk4 and Cdk6, which are the catalytic units of cyclin D1, was unchanged in metformin-treated QGP-1 cells (Figure 3). For confirmation, we detected a reduction of phosphorylated $\mathrm{Rb}(\mathrm{pRb})$ at $72 \mathrm{~h}$ after the addition of metformin.
These results indicated that the growth of QGP-1 pancreatic neuroendocrine tumor cells was suppressed after metformin treatment by impairing cell cycle progression.

Metformin induces apoptosis of QGP-1 cells by altering apoptosis-related protein expression. To investigate how metformin influences QGP-1 cell growth, we analyzed apoptosis. The apoptotic effects of $5 \mathrm{mM}$ metformin were measured by flow cytometric analysis of annexin V-FITC/PI staining. As shown in Figure 4A, metformin induced a dramatic change in the proportion of apoptotic QGP-1 cells at $24 \mathrm{~h}$ following treatment (Figure 4A and B).

Additionally, we further investigated the modulation of upstream pro- and anti-apoptotic proteins by human apoptosis antibody array study, which can detect a range of anti and pro-apoptotic markers in the presence or absence of metformin (Figure 5A). Metformin decreased the expression 


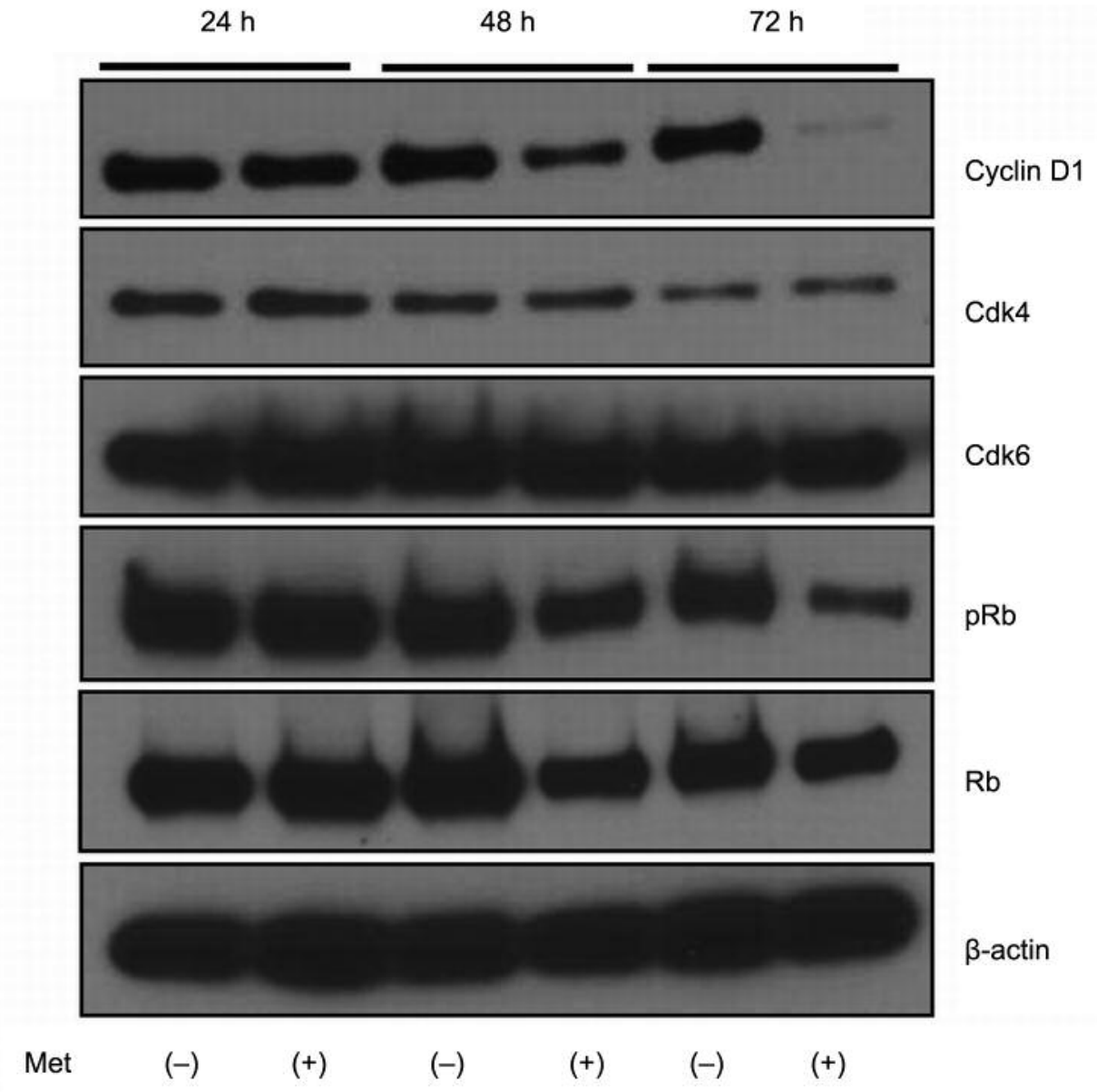

Figure 3. Western blot showing expression of cyclin D1, Cdk4, Cdk6, phosphorylated Rb (pRb), and Rb in QGP-1 cells at 24, 48, and 72 hafter addition of $5 \mathrm{mM}$ metformin. Cyclin D1 expression was decreased by $5 \mathrm{mM}$ metformin treatment (+) compared to the control (-).

of survivin and claspin in QGP-1 cells (Figure 5B). Densitometry showed that the intensities of survivin and claspin in metformin-treated QGP-1cells were $25 \%$ and $22.5 \%$, respectively, of those in untreated QGP-1 cells (Figure 5C).

These results revealed that metformin inhibited the proliferation of QGP-1 pNET cells by decreasing antiapoptosis-inducing proteins.

Association between metformin and angiogenesis of QGP-1 pNET cells. To identify angiogenic factors affected by metformin, a human angiogenesis array kit was applied to QGP-1 cells (Figure 6A). A markedly decreased level of TIMP-1 was observed in metformin-treated QGP-1 cells compared to untreated cells (Figure 6B). Quantitative results are shown in Figures 6C.

MiRNA expression signatures are different in metformintreated and untreated QGP-1 cells. Heat maps generated by
miRNA microarray analysis revealed expression of several miRNAs that are dysregulated in $5 \mathrm{mM}$ metformin-treated QGP-1 cells (Figure 7). After normalization and removing miRNAs with missing values, 241 miRNAs were used to perform hierarchical clustering. Finally, 50 significantly differentially expressed miRNAs were identified, 33 of which were significantly up-regulated and the remaining 17 were down-regulated (Table I).

Anti-tumor effect metformin in vivo. We next investigated the anti-tumor effect of metformin in vivo. Xenografted mice were administrated metformin (1 or $2 \mathrm{mg} /$ day) or PBS only intraperitoneally after subcutaneous implantation of QGP-1 cells.

Metformin was found to effectively suppress tumor growth of QGP-1 xenografts. The tumor size was significantly lower in metformin-treated mice compared to the control (Figure 8A and B). Additionally, we analyzed protein expression by immunohistochemistry to determine whether metformin also affected cell cycle regulatory proteins in vivo. Metformin 
A

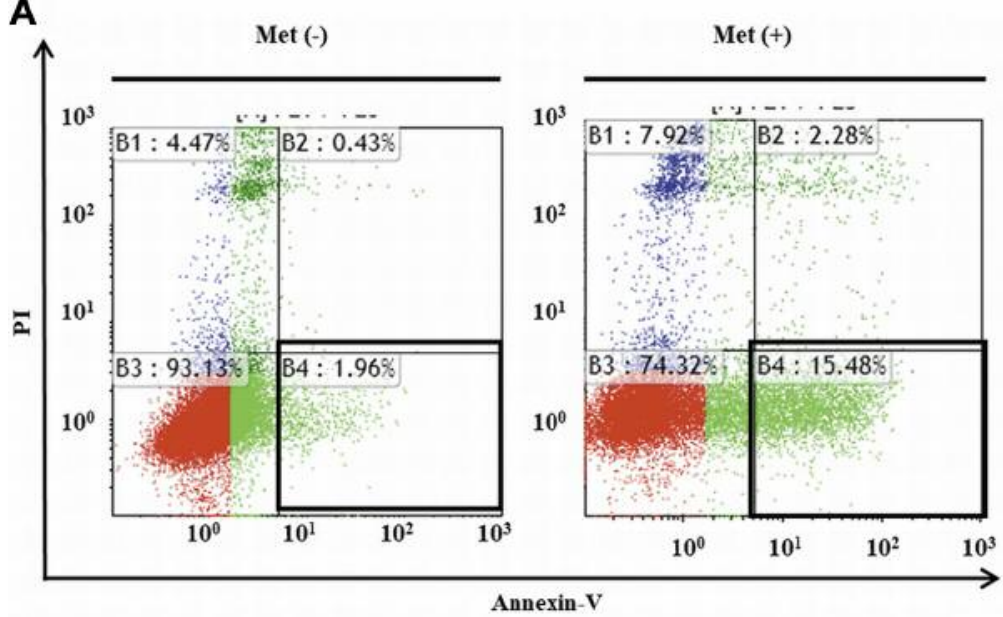

B

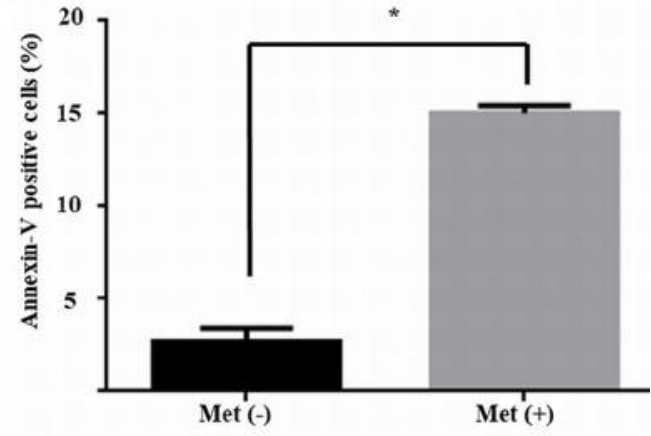

Figure 4. Metformin induces apoptosis. (A) Early apoptotic changes evoked by $5 \mathrm{mM}$ metformin at $24 \mathrm{~h}$ were assessed by flow cytometry. Annexin$V$ positive and PI-negative cells were regarded as early apoptotic (enclosed areas in bold squares). (B) Labeling index of annexin-V-positive cells. The proportion of annexin-V-positive, metformin-treated cells was higher compared to that of untreated cells (control) $\left({ }^{*} p<0.05\right.$, vs control).

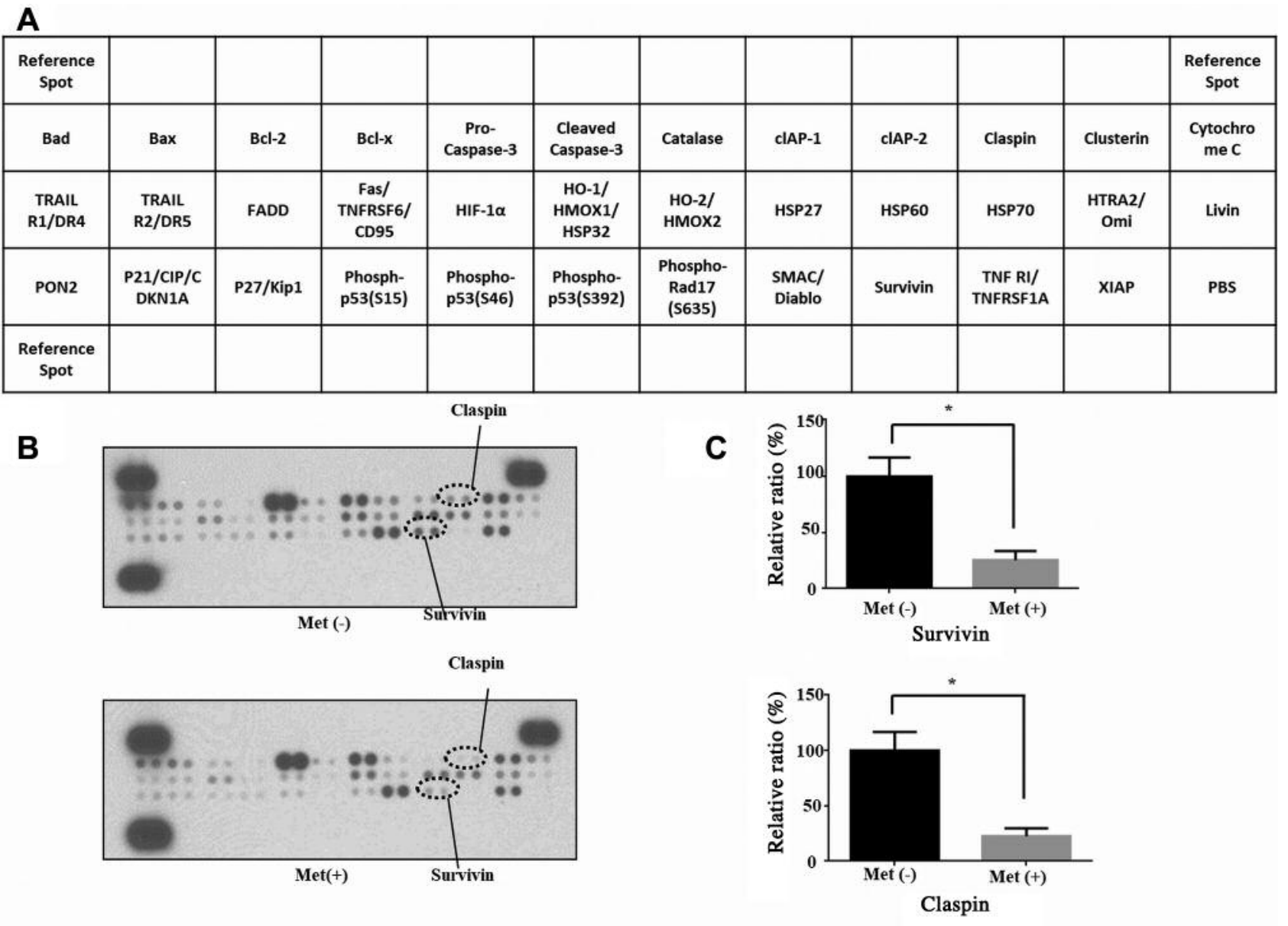

Figure 5. Metformin induces apoptosis of QGP-1 cells. (A) Analysis of apoptosis in metformin-treated QGP-1 cells revealed induction of apoptosis by metformin. (B) Apoptosis array image of 35 apoptosis-related proteins. (C) Relative ratios of survivin and claspin spots of metformin-treated to untreated cells were $25 \%$ and $22.5 \%$, respectively $\left({ }^{*} p<0.05\right.$, vs control). 


A
\begin{tabular}{|c|c|c|c|c|c|c|c|c|c|c|c|}
\hline $\begin{array}{c}\text { Reference } \\
\text { Spot }\end{array}$ & & Activin A & ADAMTS-1 & $\begin{array}{c}\text { Angiogeni } \\
n\end{array}$ & Ang-1 & Ang-2 & $\begin{array}{c}\text { Angiostatin/ } \\
\text { Plasminogen }\end{array}$ & AR & Artemin & $\begin{array}{c}\text { Reference } \\
\text { Spot }\end{array}$ \\
\hline $\begin{array}{c}\text { Coagulatio } \\
\text { n Factor III }\end{array}$ & CXCL 16 & DPPIV & EGF & EG-VEGF & Endoglin & $\begin{array}{c}\text { Endostatin } \\
\text { /Collagen } \\
\text { X VII }\end{array}$ & Endothelin-1 & $\begin{array}{c}\text { FGF } \\
\text { acidic }\end{array}$ & FGF basic & FGF-4 & FGF-7 \\
\hline GDNF & GM-CSF & HB-EGF & HGF & IGFBP-1 & IGFBP-2 & IGFBP-3 & IL-1 $\beta$ & IL-8 & LAP & Leptin & MCP-1 \\
\hline MIP-1 $\alpha$ & MMP-8 & MMP-9 & NRG1- $\beta 1$ & PTX3 & PD-ECGF & PDGF-AA & $\begin{array}{c}\text { PDGF-AB/ } \\
\text { PDGF-BB }\end{array}$ & $\begin{array}{c}\text { Persephi } \\
n\end{array}$ & PF4 & PIGF & Prolactin \\
\hline $\begin{array}{c}\text { Serpin B5 } \\
\text { Serpin E1 }\end{array}$ & Serpin F1 & TIMP-1 & TIMP-4 & $\begin{array}{c}\text { Thrombos } \\
\text { pondin-1 }\end{array}$ & $\begin{array}{c}\text { Thrombos } \\
\text { pondin-2 }\end{array}$ & uPA & $\begin{array}{c}\text { Vasohibi } \\
n\end{array}$ & VEGF & VEGF-C & \\
\hline $\begin{array}{c}\text { Reference } \\
\text { Spot }\end{array}$ & & & & & & & & & & & $\begin{array}{c}\text { Negative } \\
\text { Control }\end{array}$ \\
\hline
\end{tabular}

\section{B}
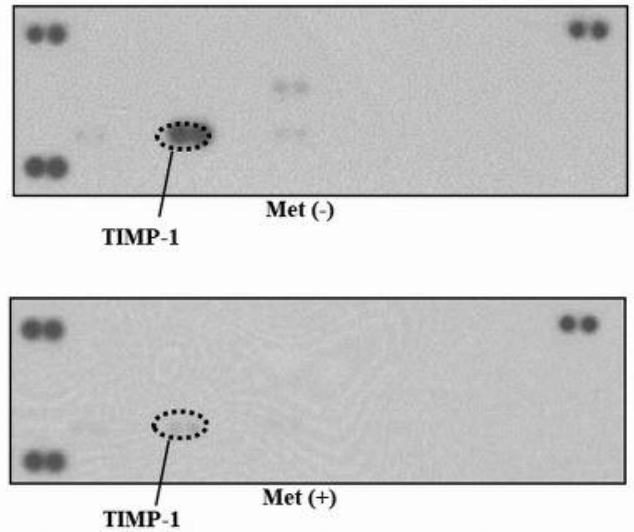

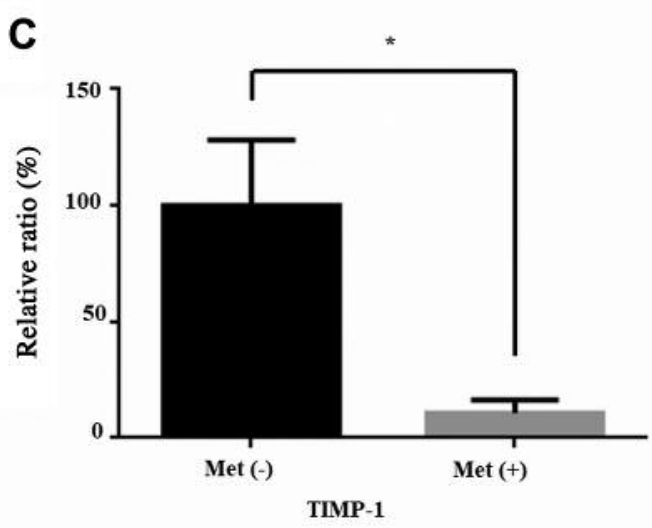

Figure 6. Effects of metformin on angiogenesis of QGP-1 cells. (A) Angiogenesis array image of 55 angiogenesis-related cytokines. (B) Humanspecific angiogenesis antibody array membranes were incubated with or without metformin in QGP-1 cells. (C) Relative levels of TIMP-1 in metformin-treated versus untreated QGP-1 cells.

decreased the expression level of cyclin D1 (Figure 9A) and reduced the expression of PCNA compared with controls (Figure 9B). In the metformin-treated group, expression of cyclin D1 and PCNA was higher compared to the control group. The labeling index of metformin-treated cell was also higher compared to the control.

Metformin treatment had no significant effect on the body weight of animals during the course of the treatments.

\section{Discussion}

In the present study, we focused on the anti-tumor effects of metformin in pancreatic neuroendocrine tumors. The present findings are significant because we investigated the antitumor effect of metformin on pNET growth both in vitro and in vivo. Metformin induced cell cycle arrest at $\mathrm{G}_{0} / \mathrm{G}_{1}$ phase through modulation of the cell cycle-regulating protein cyclin D1 in QGP-1 pNET cells. These results are consistent with findings reported in a previous study of metformin effects on various cancer cells (17). More importantly, the anti-proliferative effect of metformin on pNETs was validated in an animal model. To the best of our knowledge, this is the first study to show that metformin inhibits pNET growth by inducing a cell cycle arrest in vivo.

Metformin (dimethyl-biguanide) is one of the most widely used anti-hyperglycemic drugs and insulin sensitizers, which inhibits hepatic glucose production and enhances peripheral glucose uptake (11). It has been associated with reduced incidence of several types of cancer in patients with type 2 diabetes (8). Among the postulated mechanisms for such a benefit are: i) inhibition of cancer cell growth, ii) suppression of HER2 overexpression, and iii) inhibition of mTOR (18-20). Metformin has also been shown to inhibit cancer cell proliferation $(11,15,21)$, and reduce the risk of cancer and improve cancer prognoses in type 2 diabetes patients (22). Furthermore, metformin has been shown to inhibit cancer cell proliferation in vitro (17).

The cell cycle is divided in two phases: i) interphase $\left(\mathrm{G}_{0}\right)$ and ii) $M$ phase $\left(G_{1}, S\right.$, and $\left.G_{2}\right)$. Cyclin $D 1$ and Cdks are important cell cycle regulatory proteins that play a positive role during the crucial restriction point of $\mathrm{G}_{1} / \mathrm{S}$ transition (23, 24). PCNA is a DNA clamp that acts as a processivity for 


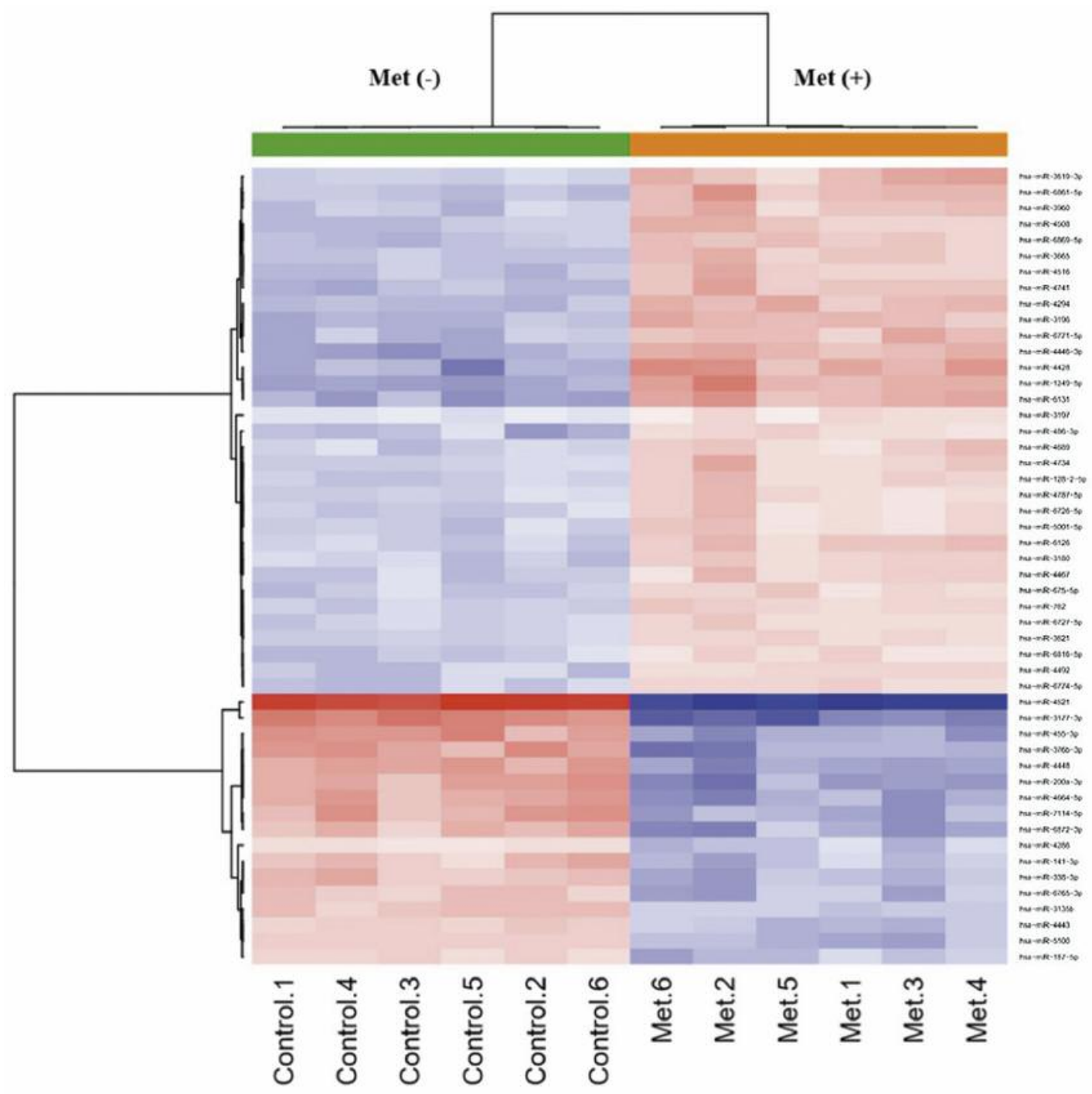

Figure 7. Hierarchical clustering of QGP-1 cells cultured with or without metformin. The analyzed samples are shown in the columns, and the miRNAs are presented in the rows. The miRNA clustering color scale presented at the top indicates the relative miRNA expression levels with red and blue representing high and low expression levels, respectively.

DNA polymerase $\delta$ in eukaryotic cells, and is essential for replication (25). Our in vitro experiments verified that metformin induces cell cycle arrest at $\mathrm{G}_{0} / \mathrm{G}_{1}$ phase, which was accompanied by the down-regulation of cyclin D1. We found that metformin induces the arrest of proliferative cells and, indeed, metformin down-regulated the expression of cyclin D1 and PCNA in vitro and in vivo. These results indicate that metformin may reduce the expression of cell cycle-related proteins and induce cell cycle arrest in pNET cells.

Metformin has been shown to inhibit cell proliferation by inducing apoptosis in various cancer cell lines, such as prostate (26), lung (27), and breast (28) cancer lines. We also observed that metformin induced QGP-1 cell apoptosis.
Additionally, survivin and claspin expression was decreased in metformin-treated QGP-1 cells. Survivin is an inhibitor of apoptosis and is overexpressed in pancreatic ductal carcinoma $(29,30)$. In addition, high tissue and serum expression of survivin is a poor prognostic marker in pancreatic ductal carcinoma (31). Claspin is also required for efficient DNA replication during normal $\mathrm{S}$ phase and is highly expressed in more aggressive cancers $(32,33)$. Collectively, the present data suggested that metformin induced apoptosis and inhibited QGP-1 cell proliferation by suppressing the expression of both survivin and claspin.

The tumor microenvironment is the product of crosstalk between different cell types, and it plays a critical role in 

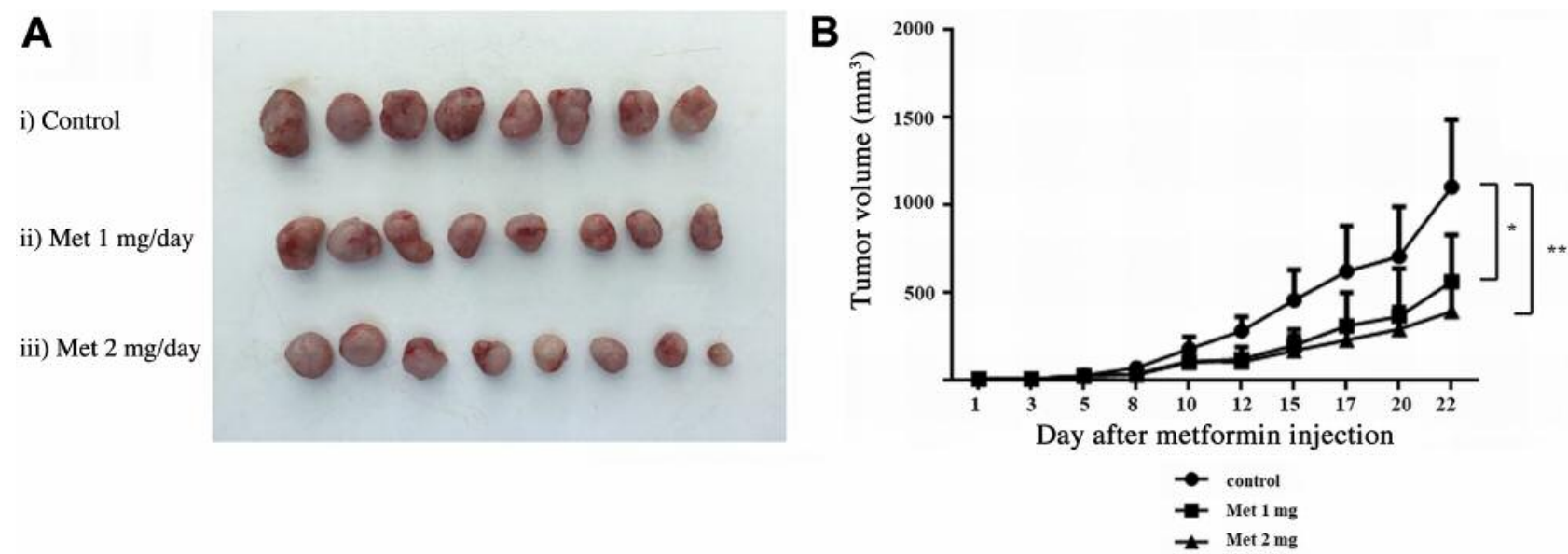

Figure 8. Metformin inhibits the growth of QGP-1 cell xenografts in nude mice. QGP-1 cells were subcutaneously implanted into the flanks of nude mice. When the tumors became palpable, 0, 1 or $2 \mathrm{mg}$ metformin was intraperitoneally injected five times per week for 22 days. (A) Photographs showing the representative xenograft tumors on metformin-treated or vehicle-treated nude mice. (B) Tumor growth curves of control and metformin groups. Tumors were significantly smaller in metformin-treated mice compared to vehicle-treated mice. Each point represents the mean \pm standard deviation of eight animals $(* p<0.05$ and $* * p<0.01$, vs control).

A

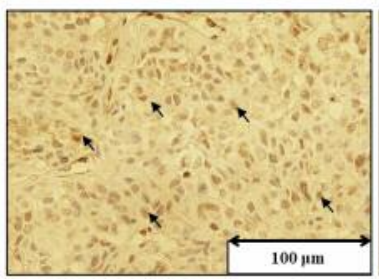

Control

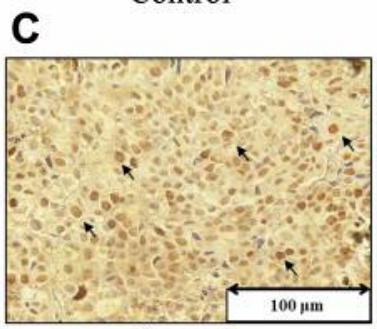

Control

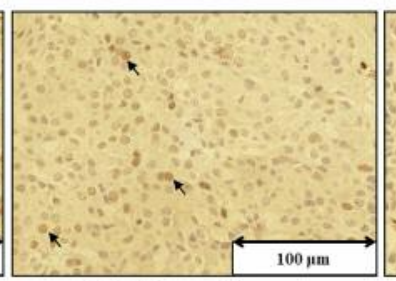

Met $1 \mathrm{mg} /$ day

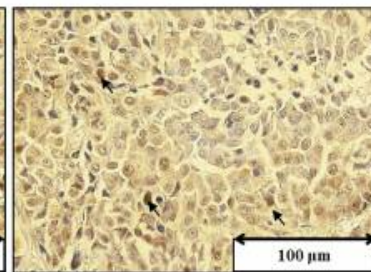

Met $1 \mathrm{mg} /$ day

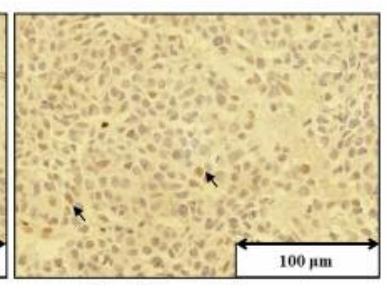

Met $2 \mathrm{mg} /$ day

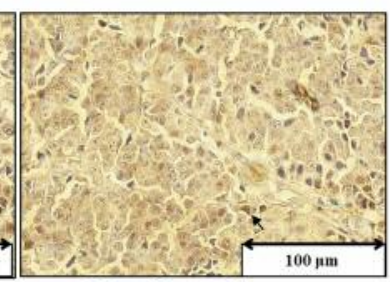

Met $2 \mathrm{mg} /$ day

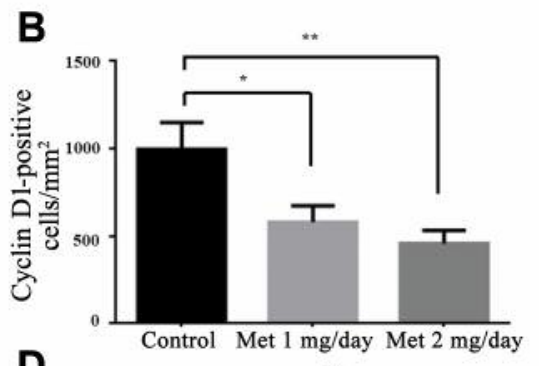

D

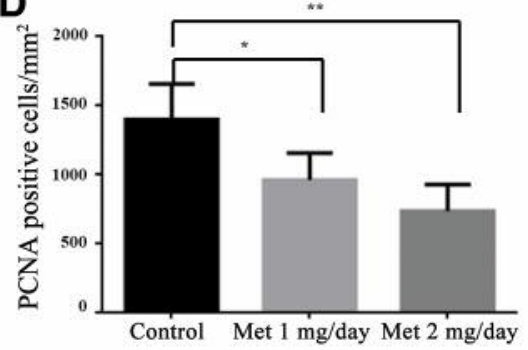

Figure 9. (A) Immunohistochemical staining of cyclin D1 in cancerous tissues from metformin-treated and control groups of xenografted mice. Cyclin D1-positive cells (black arrows) were decreased in mice treated with metformin (1 or $2 \mathrm{mg}$ ). a: control, b: $1 \mathrm{mg} /$ day metformin, c: $2 \mathrm{mg} /$ day metformin. (B) Cyclin D1-positive cells in metformin-treated mice were reduced compared to untreated mice. (C) Immunohistochemical staining of PCNA in cancerous tissues from metformin-treated and control groups of xenografted mice. PCNA-positive cells (black arrows) were decreased in mice treated with metformin (1 or $2 \mathrm{mg}$ ). a: control, $b: 1 \mathrm{mg} /$ day metformin, $c: 2 \mathrm{mg} /$ day metformin. (D) PCNA-positive cells in metformin-treated mice were reduced compared with untreated mice $\left(* p<0.05\right.$ and $*^{*} p<0.01$, vs. control).

promoting the initiation and progression of malignancy (34). Using an angiogenesis antibody array, we found that the expression level of TIMP-1 was reduced in metformin-treated QGP-1 cells. TIMP-1 is an endogenous inhibitor of matrix metalloproteinases, which plays a key regulatory role in tumor progression (35). Urinal TIMP-1 may have diagnostic value to distinguish between pancreatic NETs and adenocarcinoma (36). Moreover, high TIMP-1 expression has been reported to be indicative of a poor prognosis in pancreatic and ampullary malignancies (37). Metformin reduces angiogenesis and promotes necrosis in esophageal cancer xenograft models through up-regulation of p53 and 
Table I. Statistical results and chromosomal locations of miRNAs in QGP-1 cells treated with or without metformin. Fold changes are metformin treated/non-treated. Fold change $(F C)>2.5, F C<0.4$, p-Value $<0.005$.

\begin{tabular}{lccc}
\hline miRNA & Fold-change & $p$-Value & $\begin{array}{c}\text { Chromosomal } \\
\text { localization }\end{array}$ \\
\hline Up-regulated & & & \\
hsa-miR-1249-5p & 3.714543712 & $3.37491 \mathrm{E}-08$ & $22 \mathrm{q} 13.31$ \\
hsa-miR-4428 & 3.657987938 & $2.58787 \mathrm{E}-07$ & $1 \mathrm{q} 43$ \\
hsa-miR-6131 & 3.508360895 & $2.89727 \mathrm{E}-08$ & $5 \mathrm{p} 15.2$ \\
hsa-miR-4446-3p & 3.256090127 & $2.14624 \mathrm{E}-09$ & $3 \mathrm{q} 13.2$ \\
hsa-miR-4299 & 3.199431779 & $5.56611 \mathrm{E}-05$ & $11 \mathrm{p} 15.4$ \\
hsa-miR-3196 & 2.857469354 & $2.21328 \mathrm{E}-09$ & $20 \mathrm{q} 13.33$ \\
hsa-miR-4294 & 2.734436777 & $2.38375 \mathrm{E}-09$ & $10 \mathrm{q} 11.23$ \\
hsa-miR-6861-5p & 2.702412862 & $7.87813 \mathrm{E}-08$ & $12 \mathrm{q} 24.13$ \\
hsa-miR-1290 & 2.669759159 & $6.08713 \mathrm{E}-05$ & $1 \mathrm{p} 36.13$ \\
hsa-miR-4741 & 2.663572769 & $1.33093 \mathrm{E}-08$ & $18 \mathrm{q} 11.2$ \\
hsa-miR-6771-5p & 2.593949188 & $6.80969 \mathrm{E}-08$ & \\
\hline
\end{tabular}

p21CIP1 expression (38). Our results suggested that metformin may have anti-cancer effects through a reduction of TIMP-1 to affect angiogenesis.

MicroRNAs are endogenous mediators of gene expression through their site-specific binding at the 3' untranslated region or other sites of mRNAs to either degrade their target or inactivate protein synthesis. MiRNAs regulate many biological processes, such as cancer cell proliferation, tumor growth, differentiation, apoptosis, and energy metabolism (39). We identified miRNAs associated with the anti-tumor effects of metformin in QGP-1 cells using miRNA expression arrays. Numerous microRNAs were significantly altered following metformin treatment of QGP-1 cells. MiR-200a-3p was significantly down-regulated in metformin-treated QGP-1 cells. The miR-200 family is widely recognized as a tumor suppressor through the regulation of epithelial-to-mesenchymal transition in various cancer types (40). Up-regulation of the miR-200a-3p family has been reported in esophageal cancer (41). Zang et al., have reported that miR-200a-3p promotes cell proliferation of esophageal cancer by post-transcriptionally regulating CRMP1 (cytoplasmic collapsin response mediator protein 1) (42). Based on previous studies, our data suggest that the altered miRNAs may result from the antitumoral effects of metformin.

In conclusion, our results revealed that metformin inhibits human QGP-1 pancreatic NET cell proliferation by inducing cell cycle arrest and apoptosis. In the near future, metformin may be used as a first line drug for cancer patients with diabetes.

\section{Conflicts of Interest}

The Authors disclose no potential conflicts of interest.

\begin{tabular}{lccc}
\hline miRNA & Fold change & $p$-Value & $\begin{array}{c}\text { Chromosomal } \\
\text { localization }\end{array}$ \\
\hline Down-regulated & & & \\
hsa-miR-4521 & 0.046440459 & $6.78411 \mathrm{E}-12$ & $17 \mathrm{p} 13.1$ \\
hsa-miR-3177-3p & 0.143700706 & $7.98764 \mathrm{E}-10$ & $16 \mathrm{p} 13.3$ \\
hsa-miR-200a-3p & 0.242553967 & $2.49711 \mathrm{E}-08$ & $1 \mathrm{p} 36.33$ \\
hsa-miR-455-3p & 0.244852948 & $2.76534 \mathrm{E}-08$ & $9 \mathrm{q} 32$ \\
hsa-miR-4448 & 0.254274393 & $1.68824 \mathrm{E}-09$ & $3 \mathrm{q} 27.1$ \\
hsa-miR-376b-3p & 0.255135375 & $5.1952 \mathrm{E}-07$ & $14 \mathrm{q} 32.31$ \\
hsa-miR-4664-5p & 0.267491463 & $3.13495 \mathrm{E}-08$ & $8 \mathrm{q} 24.3$ \\
hsa-miR-7114-5p & 0.283540161 & $1.16775 \mathrm{E}-07$ & $9 \mathrm{q} 34.3$ \\
hsa-miR-6872-3p & 0.307194913 & $4.74446 \mathrm{E}-07$ & $3 \mathrm{p} 21.31$ \\
hsa-miR-615-5p & 0.335025224 & 0.000561165 & $12 \mathrm{q} 13.13$ \\
hsa-miR-153-3p & 0.364861836 & 0.000162513 & \\
hsa-miR-338-3p & 0.369720719 & $1.04795 \mathrm{E}-07$ & $17 \mathrm{q} 25.3$ \\
hsa-miR-141-5p & 0.38487385 & $2.78659 \mathrm{E}-06$ & $12 \mathrm{p} 13.31$ \\
hsa-miR-141-3p & 0.389859654 & $5.31337 \mathrm{E}-07$ & $12 \mathrm{p} 13.31$ \\
\hline
\end{tabular}

\section{Authors' Contributions}

HY and KK designed experiments. HK, KF, DW, KK, AM, KT, HK, and $\mathrm{HI}$ conducted the experiments, data analysis, and final drafting and writing of the manuscript. SF was involved in the research design and contributed to drafting of the manuscript. TM was involved in the research design and drafting of the final manuscript. All authors have read and approved the final version of the manuscript.

\section{Acknowledgements}

We thank Ms. Kayo Hirose, Ms. Keiko Fujikawa, Ms. Megumi Okamura, and Ms. Fuyuko Kokado for their skillful technical assistance.

\section{References}

1 Halfdanarson TR, Rabe KG, Rubin $\mathrm{J}$ and Petersen GM: Pancreatic neuroendocrine tumors (PNETs): incidence, prognosis and recent trend toward improved survival. Ann Oncol 19(10): 1727, 2008. PMID: 18515795. DOI: 10.1093/annonc/mdn351

2 Halfdanarson TR, Rubin J, Farnell MB, Grant CS and Petersen GM: Pancreatic endocrine neoplasms: epidemiology and prognosis of pancreatic endocrine tumors. Endocr Relat Cancer 15(2): 409, 2008. PMID: 18508996. DOI: 10.1677/ERC-07-0221

3 Hallet J, Law CH, Cukier M, Saskin R, Liu N and Singh S: Exploring the rising incidence of neuroendocrine tumors: a population-based analysis of epidemiology, metastatic presentation, and outcomes. Cancer 121(4): 589-597, 2015. PMID: 25312765. DOI: 10.1002/cncr.29099

4 Metz DC and Jensen RT: Gastrointestinal neuroendocrine tumors: pancreatic endocrine tumors. Gastroenterology 135(5): 1469, 2008. PMID: 18703061. DOI: 10.1053/j.gastro.2008.05.047

5 Pavel M: Translation of molecular pathways into clinical trials of neuroendocrine tumors. Neuroendocrinology 97(1): 99-112, 2013. PMID: 22508344. DOI: 10.1159/000336089 
6 Yao JC, Shah MH, Ito T, Bohas CL, Wolin EM, Van Cutsem E, Hobday TJ, Okusaka T, Capdevila J, de Vries EG, Tomassetti P, Pavel ME, Hoosen S, Haas T, Lincy J, Lebwohl D and Öberg K: RAD001 in Advanced Neuroendocrine Tumors, Third Trial (RADIANT-3) Study Group. Everolimus for advanced pancreatic neuroendocrine tumors. N Engl J Med 364(6): $514-$ 523, 2011. PMID: 21306238. DOI: 10.1056/NEJMoa 1009290

7 Libby G, Donnelly LA, Donnan PT, Alessi DR, Morris AD and Evans JM: New users of metformin are at low risk of incident cancer: a cohort study among people with type 2 diabetes. Diabetes Care 32(9): 1620-1625, 2009. PMID: 19564453. DOI: $10.2337 / \mathrm{dc} 08-2175$

8 Decensi A, Puntoni M, Goodwin P, Cazzaniga M, Gennari A, Bonanni B and Gandini S: Metformin and cancer risk in diabetic patients: a systematic review and meta-analysis. Cancer Prev Res (Phila) 3(11): 1451-1461, 2010. PMID: 20947488. DOI: 10.1158/1940-6207.CAPR-10-0157

9 Noto $\mathrm{H}$, Goto A, Tsujimoto $\mathrm{T}$ and Noda M: Cancer risk in diabetic patients treated with metformin: a systematic review and meta-analysis. PLoS One 7(3): e33411, 2012. PMID: 22448244 DOI: 10.1371/journal.pone.0033411

10 Pierotti MA, Berrino F, Gariboldi M, Melani C, Mogavero A, Negri T, Pasanisi P and Pilotti S: Targeting metabolism for cancer treatment and prevention: metformin, an old drug with multi-faceted effects. Oncogene 32(12): 1475-1487, 2013. PMID: 22665053 DOI: 10.1038/onc.2012.181

11 Ben Sahra I, Laurent K, Loubat A, Giorgetti-Peraldi S, Colosetti P, Auberger P, Tanti JF, Le Marchand-Brustel Y and Bost F: The antidiabetic drug metformin exerts an antitumoral effect in vitro and in vivo through a decrease of cyclin D1 level. Oncogene 27(25): 3576-3586, 2008. PMID: 18212742. DOI: $10.1038 /$ sj.onc. 1211024

12 Pusceddu S, Vernieri C, Di Maio M, Marconcini R, Spada F, Massironi S, Ibrahim T, Brizzi MP, Campana D, Faggiano A, Giuffrida D, Rinzivillo M, Cingarlini S, Aroldi F, Antonuzzo L, Berardi R, Catena L, De Divitiis C, Ermacora P, Perfetti V, Fontana A, Razzore P, Carnaghi C, Davì MV, Cauchi C, Duro M, Ricci S, Fazio N, Cavalcoli F, Bongiovanni A, La Salvia A, Brighi N, Colao A, Puliafito I, Panzuto F, Ortolani S, Zaniboni A, Di Costanzo F, Torniai M, Bajetta E, Tafuto S, Garattini SK, Femia D, Prinzi N, Concas L, Lo Russo G, Milione M, Giacomelli L, Buzzoni R, Delle Fave G, Mazzaferro V and de Braud F: Metformin use is associated with longer progressionfree survival of patients with diabetes and pancreatic neuroendocrine tumors receiving everolimus and/or somatostatin analogues. Gastroenterology 155(2): 479-489, 2018. PMID: 29655834. DOI: $10.1053 /$ j.gastro.2018.04.010

13 Sharma PS, Sharma R and Tyagi R: Inhibitors of cyclin dependent kinases: useful targets for cancer treatment. Curr Cancer Drug Targets 8(1): 53-75, 2008. PMID: 18288944. DOI: $10.2174 / 156800908783497131$

14 Guo SS, Wu X, Shimoide AT, Wong J, Moatamed F and Sawicki MP: Frequent overexpression of cyclin D1 in sporadic pancreatic endocrine tumours. J Endocrinol 179(1): 73-79, 2003. PMID: 14529567. DOI: $10.1677 /$ joe. 0.1790073

15 Kato K, Gong J, Iwama H, Kitanaka A, Tani J, Miyoshi H, Nomura K, Mimura S, Kobayashi M, Aritomo Y, Kobara H, Mori H, Himoto T, Okano K, Suzuki Y, Murao K and Masaki T: The antidiabetic drug metformin inhibits gastric cancer cell proliferation in vitro and in vivo. Mol Cancer Ther 11(3): 549-560, 2012. PMID: 22222629. DOI: 10.1158/1535-7163. MCT-11-0594
16 D’Incalci M, Colombo T, Ubezio P, Nicoletti I, Giavazzi R, Erba E, Ferrarese L, Meco D, Riccardi R, Sessa C, Cavallini E, Jimeno $\mathbf{J}$ and Faircloth GT: The combination of yondelis and cisplatin is synergistic against human tumor xenografts. Eur J Cancer 39: 1920-1926, 2003. PMID: 12932672. DOI: 10.1016/s0959-8049(03)00490-8

17 Vlotides G, Tanyeri A, Spampatti M, Zitzmann K, Chourdakis M, Spttl C, Maurer J, Nölting S, Göke B and Auernhammer CJ: Anticancer effects of metformin on neuroendocrine tumor cells in vitro. Hormones (Athens) 13(4): 498-508, 2014. PMID: 25402373. DOI: $10.14310 /$ horm.2002.1517

18 Alimova IN, Liu B, Fan Z, Edgerton SM, Dillon T, Lind SE and Thor AD: Metformin inhibits breast cancer cell growth, colony formation and induces cell cycle arrest in vitro. Cell Cycle 8(6): 909-915, 2009. PMID: 19221498. DOI: 10.4161/cc.8.6.7933

19 Vazquez-Martin A, Oliveras-Ferraros C and Menendez JA: The antidiabetic drug metformin suppresses HER2 (erbB-2) oncoprotein overexpression via inhibition of the mTOR effector p70S6K1 in human breast carcinoma cells. Cell Cycle 8(1): 8896, 2009. PMID: 19106626. DOI: 10.4161/cc.8.1.7499

20 Vázquez-Martín A, Oliveras-Ferraros C, del Barco S, MartínCastillo B and Menéndez JA: mTOR inhibitors and the antidiabetic biguanide metformin: new insights into the molecular management of breast cancer resistance to the HER2 tyrosine kinase inhibitor lapatinib (Tykerb). Clin Transl Oncol 11(7): 455459, 2009. PMID: 19574203. DOI: 10.1007/s12094-009-0384-0

21 Kato K, Iwama H, Yamashita T, Kobayashi K, Fujihara S, Fujimori T, Kamada H, Kobara H and Masaki T: The anti-diabetic drug metformin inhibits pancreatic cancer cell proliferation in vitro and in vivo: Study of the microRNAs associated with the antitumor effect of metformin. Oncol Rep 35(3): 1582-1592, 2016. PMID: 26708419. DOI: 10.3892/or.2015.4496

22 Franciosi M, Lucisano G, Lapice E, Strippoli GF, Pellegrini F and Nicolucci A: Metformin therapy and risk of cancer in patients with type 2 diabetes: systematic review. PloS One 8: e71583, 2013. PMID: 23936520. DOI: 10.1371/journal.pone.0071583

23 Masaki T, Shiratori Y, Rengifo W, Igarashi K, Yamagata M, Kurokohchi K, Uchida N, Miyauchi Y, Yoshiji H, Watanabe S, Omata $\mathrm{M}$ and Kuriyama S: Cyclins and cyclin-dependent kinases: comparative study of hepatocellular carcinoma versus cirrhosis. Hepatology 37(3): 534-543, 2003. PMID: 12601350. DOI: $10.1053 /$ jhep.2003.50112

24 Matsuda Y: Molecular mechanism underlying the functional loss of cyclin-dependent kinase inhibitors p16 and p27 in hepatocellular carcinoma. World J Gastroenterol 14(11): 173440, 2008. PMID: 18350604. DOI: 10.3748/wjg.14.1734

25 Juríková M, Danihel L, Polák Š and Varga I: Ki67, PCNA, and MCM proteins: Markers of proliferation in the diagnosis of breast cancer. Acta Histochem 30084-30088, 2016. PMID: 27246286. DOI: $10.1016 /$ j.acthis.2016.05.002

26 Colquhoun AJ, Venier NA, Vandersluis AD, Besla R, Sugar LM, Kiss A, Fleshner NE, Pollak M, Klotz LH and Venkateswaran $\mathrm{V}$ : Metformin enhances the antiproliferative and apoptotic effect of bicalutamide in prostate cancer. Prostate Cancer Prostatic Dis 15(4): 346-352, 2012. PMID: 27246286. DOI: 10.1016/j.acthis. 2016.05.002

27 Ashinuma H, Takiguchi Y, Kitazono S, Kitazono-Saitoh M, Kitamura A, Chiba T, Tada Y, Kurosu K, Sakaida E, Sekine I, Tanabe N, Iwama A, Yokosuka O and Tatsumi K: Antiproliferative action of metformin in human lung cancer cell lines. Oncol Rep 28: 8-14, 2012. PMID: 22576795. DOI: 10.3892/or.2012.1763 
28 Queiroz EA, Puukila S, Eichler R, Sampaio SC, Forsyth HL, Lees SJ, Barbosa AM, Dekker RF, Fortes ZB and Khaper N: Metformin induces apoptosis and cell cycle arrest mediated by oxidative stress, AMPK and FOXO3a in MCF-7 breast cancer cells. PLoS One 9: e98207, 2014. PMID: 24858012. DOI: 10.1371/journal.pone .0098207

29 Satoh K, Kaneko K, Hirota M, Masamune A, Satoh A and Shimosegawa T: Expression of survivin is correlated with cancer cell apoptosis and is involved in the development of human pancreatic duct cell tumors. Cancer 92: 271-278, 2001. PMID: 11466679. DOI: 10.1002/1097-0142(20010715)92:2<271::aidcncr1319>3.0.co;2-0

30 Kami K, Doi R, Koizumi M, Toyoda E, Mori T, Ito D, Fujimoto K, Wada M, Miyatake S, and Imamura M: Survivin expression is a prognostic marker in pancreatic cancer patients. Surgery 136: $443-$ 448, 2004. PMID: 15300213. DOI: 10.1016/j.surg.2004.05.023

31 Dong H, Qian D, Wang Y, Meng L, Chen D, Ji X and Feng W: Survivin expression and serum levels in pancreatic cancer. World J Surg Oncol 13: 189, 2015. PMID: 26016480. DOI: 10.1186/ s12957-015-0605-7

32 Allera-Moreau C, Rouquette I, Lepage B, Oumouhou N, Walschaerts M, Leconte E, Schilling V, Gordien K, Brouchet L, Delisle MB, Mazieres J, Hoffmann JS, Pasero P and Cazaux C: DNA replication stress response involving PLK1, CDC6, POLQ, RAD51 and CLASPIN upregulation prognoses the outcome of early/mid-stage non-small cell lung cancer patients. Oncogenesis 1: e30, 2012. PMID: 23552402. DOI: 10.1038/oncsis.2012.29

33 Verlinden L, Vanden Bempt I, Eelen G, Drijkoningen M, Verlinden I, Marchal K, De Wolf-Peeters C, Christiaens MR, Michiels L, Bouillon R and Verstuyf A: The E2F-regulated gene Chk1 is highly expressed in triple-negative estrogen receptor/progesterone receptor/HER-2 breast carcinomas. Cancer Res 67: 6574-6581, 2007. PMID: 17638866. DOI: 10.1158/0008-5472.CAN-06-3545

34 Samples J, Willis M and Klauber-DeMore N: Targeting angiogenesis and the tumor microenvironment. Surg Oncol Clin N Am 22: 629639, 2013. PMID: 24012392. DOI: 10.1016/j.soc.2013.06.002

35 Zeng ZS, Cohen AM, Zhang ZF, Stetler-Stevenson W and Guillem JG: Elevated tissue inhibitor of metalloproteinase 1 RNA in colorectal cancer stroma correlates with lymph node and distant metastases. Clin Cancer Res 1: 899-906, 1995. PMID: 9816060.
36 Roy R, Zurakowski D, Wischhusen J, Frauenhoffer C, Hooshmand S, Kulke M and Moses MA: Urinary TIMP-1 and MMP-2 levels detect the presence of pancreatic malignancies. Br J Cancer 111(9): 1772-1779, 2014. PMID: 25137018. DOI: 10.1038/bjc.2014.462

37 Bramhall SR, Stamp GW, Dunn J, Lemoine NR and Neoptolemos JP: Expression of collagenase (MMP2), stromelysin (MMP3) and tissue inhibitor of the metalloproteinases (TIMP1) in pancreatic and ampullary disease. Br J Cancer 73(8): 972-978, 1996. PMID: 8611434. DOI: $10.1038 /$ bjc. 1996.190

38 Cai X, Hu X, Tan X, Cheng W, Wang Q, Chen X, Guan Y, Chen C and Jing X: Metformin induced AMPK activation, G0/G1 phase cell cycle arrest and the inhibition of growth of esophageal squamous cell carcinomas in vitro and in vivo. PLoS One 10(7): e0133349, 2015. PMID: 26196392. DOI: 10.1371/journal.pone.0133349

39 Bao B, Azmi AS, Ali S, Zaiem F and Sarkar FH: Metformin may function as anti-cancer agent via targeting cancer stem cells: the potential biological significance of tumor-associated miRNAs in breast and pancreatic cancers. Ann Transl Med 2(6): 59, 2014. PMID: 25333034. DOI: 10.3978/j.issn.2305-5839.2014.06.05

40 Burk U, Schubert J, Wellner U, Schmalhofer O, Vincan E, Spaderna $\mathrm{S}$ and Brabletz T: A reciprocal repression between ZEB1 and members of the miR-200 family promotes emt and invasion in cancer cells. EMBO Rep 9: 582-589, 2008. PMID: 18483486. DOI: 10.1038/embor.2008.74

41 Liu SG, Qin XG, Zhao BS, Qi B, Yao WJ, Wang TY, Li HC and Wu XN: Differential expression of miRNAs in esophageal cancer tissue. Oncol Lett 5: 1639-1642, 2013. PMID: 23761828. DOI: $10.3892 / \mathrm{ol} .2013 .1251$

42 Zang Y, Tai Y, Wan B and Jia X: miR-200a-3p promotes the proliferation of human esophageal cancer cells by posttranscriptionally regulating cytoplasmic collapsin response mediator protein-1. Int J Mol Med 38(5): 1558-1564, 2016. PMID: 28025999. DOI: 10.3892/ijmm.2016.2758

Received November 8, 2019

Revised November 22, 2019 Accepted November 25, 2019 